\title{
Civil-Service Reforms and Communist Legacy: The Case of Slovakia
}

\author{
Katarína Staroňová ${ }^{1}$
}

\begin{abstract}
Civil-service reforms in Central and Eastern European countries (CEEC) in the last decade have focused on various tools that would decrease politicization and increase the professionalization of civil service, in other words introducing a merit system in the civil service. At the same time, there was a need to attract professionals from practice into the civil service to design and implement other necessary sectoral reforms. Different countries have undertaken different trajectories of reforms. To some extent, Slovakia responded to these challenges and introduced HR reforms in civil service in order to streamline the recruitment and motivate young qualified candidates, reduce high turnover and create senior civil service, such as the "fast stream system" and "nominated civil service". However, these had only limited success. The creation of functioning human-resource management system and approaches is undoubtedly the main area of failure in civil-service reform, not only in Slovakia but in most CEE countries. This paper seeks to understand these reforms from a historical institutionalist perspective, emphasizing the influence of institutional (communist) legacies on current empirical patterns.
\end{abstract}

\section{Key words:}

civil service, historical legacies, professionalization, human-resource management, Slovakia

\section{Introduction}

A professional civil service is the cornerstone of an effectively performing public sector. Politicization is generally seen as the primary impediment to successful ad-

1 Associate Professor, Institute of Public Policy, Faculty of Social and Economic Sciences, Comenius University, Bratislava, Slovakia. 
ministrative development (Verheijen 2001; Pierre and Peters 2004), as it runs contrary to the principles of merit, professionalism and permanence that are essential foundations of a functioning civil service. The transition of Central and Eastern European countries into modern democracies in the past two decades brought a lot of questions and problems connected with institutional redesign, including questions regarding the clear division between political and administrative officials. This interaction between elected politicians and the permanent career civil servants is a central theme of institutional politics. The relations between these two actors at the centre of government affects the capacity of governments to make and implement policies to the extent expected from modern political systems. The relationship between politicians and civil servants is of particular relevance for the new EU member countries from Central and Eastern Europe.

In the last years prior to EU accession reforms were conducted in candidate states to bring about the formalization of politico-administrative relations and compliance with the "principles of the European Administrative Space". These principles of European public administration were developed by the EU and Sigma ${ }^{2}$ as part of the EU's attempt to develop an overall public-administration reform policy (SIGMA 1998), which could help applicant countries to meet the Copenhagen and Madrid criteria ${ }^{3}$. Thus, this "constructed European tradition" (Verheijen 2010) played an important role for initial reforms in CEE countries, particularly in bringing in merit-oriented civil-service laws. Yet, these reforms have progressed slowly, and although measures have been introduced that would hinder the politicians to appoint and dismiss top civil servants at their will in most CEE countries (Verheijen 2010; Staroňová and Gajduschek 2013), the civil-service systems in CEE countries remain incompatible with the principles of professionalism and neutrality.

There had been very little change in the period after the accession in 2004 in the overall situation, and even those progressive measures often seem to be shortlived. A SIGMA study (2009) which examined CEE civil-service reforms concluded that there is: 1) continued politicization; 2) an ongoing failure to create a profes-

2 Sigma is a joint initiative of the OECD and the European Union, principally financed by the EU. SIGMA supports European Union candidates, potential candidates and European Neighbourhood Policy partners in their public-administration reforms.

3 In 1993, at the Copenhagen European Council, the Union took a decisive step towards the fifth enlargement, agreeing that "the associated countries in Central and Eastern Europe that so desire shall become members of the European Union." Thus, enlargement was no longer a question of "if", but "when". Concerning the timing, the European Council states: "Accession will take place as soon as an associated country is able to assume the obligations of membership by satisfying the economic and political conditions required." At the same time, it defined the membership criteria, which are often referred to as the "Copenhagen criteria". The Madrid European Council in December 1995 stressed that membership criteria also require the candidate country to have created the conditions for its integration through the adjustment of its administrative structures. While it is important that European Community legislation is transposed into national legislation, it is even more important that the legislation is implemented effectively through appropriate administrative and judicial structures. 
sional merit-based system; and 3) a lack of effective measures to improve the quality and stability of staffing through appropriate recruitment remuneration, promotion and career-development arrangements. Moreover, the communist legacies are seen to have an impact on the reversal of the reform processes.

In the context of CEE civil-service reforms, Slovakia lacked any comprehensive reform programme, and all the efforts were of an ad-hoc nature. For example, the reform package of 2003 was initiated by the Ministry of Labour, whereas the 2006 reform measures were initiated by the Ministry of Finance right before the elections. Hungary and Lithuania, on the other hand, developed a comprehensive programme in which all reforms were anchored. According to Meyer-Sahling (2009b) Slovenia, and to a lesser extent the Czech Republic, have been active administrative reformers, but the civil service has played a subordinate role in these activities. Poland has concentrated on the fight against corruption, but it has lacked both a civil-service reform plan and a wider administrative reform strategy for most of the post-accession period.

Slovakia provides an interesting case for the study of effects of communist legacy on state administration, particularly on human-resource management. On the one hand, because Slovakia was a laggard in the accession process in order to catch up with EU negotiations, civil-service law was adopted hastily with "European administrative space" in view. On the other hand, the 2002 elections brought about a right-wing coalition, which made it possible to bring major reform elements into civil service, many of which were inspired by New Public Management and which aimed at making the civil service attractive to young people and professionals. Thus, both events created massive pressure aimed at eradicating past cultural, social and administrative practices while installing new values in HR management.

This paper seeks to connect the human-resource management reforms in civil service conducted in Slovakia with institutional legacies of the communist past. To do so, I first examine the concept of institutional legacy and how legacies reside in what is expected for an institution to provide that develops over time with the institution. Then civil-service reforms are provided in a nutshell with a focus on the dependent variable in this analysis - "performance". Performance is being conceptualized first of all as survival of the reform element and second by assessing the capacity to produce the intended outcomes. The last part of the paper asks whether analysis of the reform elements can provide any explanation on the low success (and survival) rate of such reforms.

\section{Communist legacy in public administration}

Historical institutionalism and studies of administrative changes assume a linkage between administrative traditions and administrative choices of politicians and bureaucrats in conducting reforms as well as present outcomes of the reforms. 
This suggests the existence of a legacy effect of certain administrative traditions. By legacy effect we understand an "explanation that highlights the burden of the past" (Ekiert and Hanson 2003, 5) and its effects "simply as effects associated with the days gone by" (Meyer-Sahling and Yesilkagit 2011). The main argument views legacies as causes of delays or terminations of reforms or changes in administrative practices and institutions (Painter and Peters 2010).

Painter and Peters (2010) view administrative traditions as multidimensional, allowing various lenses for classification, such as geographical, historical and cultural considerations. Thus, various authors come with differing families, though there is an agreement on main ones, such as Western administrative culture, further subdivided into Anglo-American, Germanic, Napoleonic, Scandinavian. The communist administrative tradition combined one-party rule with a unitary bureaucratic state, with overarching political control by a system of party supervision.

Central and Eastern European countries share a communist legacy (soviet legacy in Painter and Peters 2010 or Leninist legacy in Ekiert and Hanson 2003). Scholars also differentiate other types of legacies, such as legacies of pre-communist times or legacies of transition. In the former one the interwar period and Habsburg tradition plays a role, since it is looked upon for inspiration as a Weberian type of model bureaucracy (Nunberg 1999). In the latter one, some authors (e.g. Verheijen 2010) argue that the period leading to EU accession has the potential to become yet another legacy that will be used for explanations of post-accession varieties.

In the communist era the leading role in the state and society was played by the Communist Party, which has essentially induced interventions of political parties into human-resource management, which became characteristics of post-communist executive governance as much as it was a central feature of the communist era (Goetz and Wollmann 2001; Meyer-Sahling 2004). Another feature of the communist legacy relates to "bending and breaking the rules" for the sake of political goal achievement (Painter and Peters 2010). In sum, civil-service politicization, discretionary power in human-resource management exercised by politicians and disregard towards formal rules are all considered to be the patterns of communist legacy. The communist administrative tradition may, therefore, be one of the causes that hampered the civil-service reform in Slovakia that brought about the HR management elements.

Nevertheless, Meyer-Sahling (2009a) warns that in legacy analysis it is important to understand the mechanics of legacy reproduction or "legacification". Several authors distinguish between two mechanisms of legacy effects (Peters 1999, MeyerSahling 2009a, Peters and Painter 2010): a) inherited ideas and modes of thinking preserved and passed on by actors (knowledge, skills, behaviour); b) inherited structures and institutions. Particulaly, the ideas tend to provide a set of ready solutions for policy problems that arise within their domain (Peters 1999). Regardless of the mechanics of the legacy effect, administrative tradition interacts with other 
reform determinants in three possible ways (Meyer-Sahling and Yesilkagit 2011): a) administrative traditions shape more proximate factors; $b$ ) administrative traditions are shaped by short-term factors, such as economic crises or reform entrepreneurs who trigger reforms; c) the EU eclipses the administrative tradition due to its proximity to reform.

\section{Explaining civil-service reforms in Slovakia after the fall of communism}

Most of the transition countries did not have civil-service laws after the fall of communism and relied upon the general Labour code applicable to all employees, including Slovakia. After the fall of communism, there was a need to replace the previous unified soviet system of public administration. The soviet-style personnel system was largely followed, with no relevant forces advocating an alternative merit system. Delays in reforms have led to a situation where ministries in the first decade of transformation were often over-staffed, as those that remained in the administration were generally not interested in changing jobs, while new posts were unable to attract staff. This created problems in particular for new functions, such as policyanalysis posts, project management, reform implementation and, last but not least, civil servants dealing with EU matters.

After 1990, the civil service had not been a major issue on the political agenda until EU membership became a priority after the 1998 elections, and building a merit system became a necessity for that, as expressed by EU requirements. In fact, during the 1994-1998 era of Mečiar rule ${ }^{4}$ not only was no effort made for the introduction of laws that would affect the behaviour of state employees, but the politicization of the civil service increased (Staroňová and Láštic 2011). The practice of the first years after the fall of communism, when each incoming government tried to place its own people into all key positions (sometimes even two or three layers down in the hierarchy) produced a politically dependent system with significant changes at the top- and middle-level positions within the administration, with political affiliation being the main reason for changes. Politicization, patronage and lack of accountability were the key features of public administration in Slovakia during the first decade of transition.

Even the change of government in 1998 to a more democratic and pro-EU coalition did not immediately bring needed reforms to the civil service. It took several years more until the new laws on civil service were passed in 2001, and even that happened thanks to the EU pressure, when it warned that Slovakia's entry chances could be hurt if the reform was not passed. At this point it has to be stressed that

4 Vladimír Mečiar was the prime minister and leader of the HZDS party in the government of 1994-1998, who had semi-authoritarian elements in his rule and allienated Slovakia from international circles. 
as an overall reform laggard in the region, the new Dzurinda government of 1998 had different reform priorities than civil service (basically everything else required reform).

Slovakia initiated civil-service reform as late as 2001, mainly under pressure from the EU (Staroňová and Láštic 2012). The reform aimed at professionalizing the public sector by introducing two separate provisions in 2001: the Law on the public service (Act No. 313/2001), which defines the public service and covers services such as health and education; and the Law on civil service (Act No. 312/2001), which regulates the civil service in state-administration bodies. In 2003, the former law was substituted by the Law on Employees working in Services of Public Interest. The attempt to establish a professional and neutral civil service was not without difficulties. The main problems were diverging views on key issues such as conditions for tenure or pension and health-insurance rights of civil servants, where the ideas of pre-communist times were on the table vis-à-vis new ideas taken from NPM. In order to obtain EU membership, reform initiatives were formulated rapidly with little political consensus.

The Law on Civil Service also created the Civil Service Office that came into existence in 2002 to play a crucial role in recruitment, appointment and some other Human Resources (HR) decisions, most of all in career decisions. The most fundamental amendment was a package adopted in 2003 (coming into effect on 1 January 2004), regulating the status, recruitment and remuneration of civil servants, that brought new HR elements into the civil-service system, such as fast-stream recruitment, performance appraisal and nominated civil service. These HR management changes were to strengthen the capacity to attract and retain good-calibre staff at all levels, since the previous delays in the adoption of the Civil Service Law led to a situation where ministries were over-staffed, as those that remained in the administration were generally not interested in changing jobs, while new posts were unable to attract staff (Staroňová and Láštic 2012). This created problems in particular for new functions, such as policy-analysis posts, project management, reform implementation and civil servants dealing with EU matters.

However, changes introduced in 2006 abolished most elements of professional HR coordination, namely the Civil Service Office and the posts of heads of service offices were turned into political ones. The reform happened just a few weeks before the elections in 2006 with the official reason provided that the Civil Service Office was inefficient and costly. Its demise meant that there was no central control whatsoever over civil-service management and that the development of the civil service was given to the hands of individual ministries. At that point, however, it was clear that there would be a change in government, and this provision opened the space for better coalition formation. The Civil Service Office was terminated, and its functions were largely decentralized to the ministries or simply ceased to exist (e.g. the 
entry examinations became simple job interviews). In the absence of a central direction the CS system came to depend on the discretion of political appointees.

In 2009 a new Law on Civil Service was prepared that abolished many of the new HR reforms from the 2003 reform (performance appraisal, fast-stream recruitment and nominated civil service) and left behind confusion between a careerbased and a position-based system.

Thus, from the above analysis of the civil-service-law evolvement trajectory, it is clear that some fundamental changes did not sustain over time. Thus, the approach that might explain the persistence of certain patterns is historical institutionalism. In order to do so, this paper is based on mapping key human-resourcemanagement elements brought by the reform (see Table 1) into the Slovak Civil Service in 2003. This major CS law amendment is marked by many changes that attempted to make the CS more attractive for professionals to conduct reforms as well for as young applicants with the vision of a 2004 entry into the EU.

Data are gained from analyses of the relevant legislation and documents as well as interviews with key stakeholders for its implementation in practice during the period of 2013-2015.

\section{Table 1}

Reform elements under investigation

\begin{tabular}{|c|c|c|}
\hline $\begin{array}{l}\text { HR } \\
\text { aspect }\end{array}$ & Measure & Goal \\
\hline \multirow{3}{*}{ 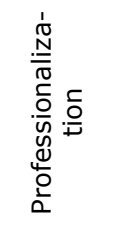 } & $\begin{array}{l}\text { Temporary civil } \\
\text { service }\end{array}$ & $\begin{array}{l}\text { to tackle political nominees (advisors) in civil service } \\
\text { (rights and duties as civil service) }\end{array}$ \\
\hline & $\begin{array}{l}\text { Nominated civil } \\
\text { service }\end{array}$ & $\begin{array}{l}\text { to introduce senior civil service with tenure } \\
\text { (professionalization of civil service) }\end{array}$ \\
\hline & $\begin{array}{l}\text { Posts of superior } \\
\text { significance }\end{array}$ & to attract professionals from practice for key posts \\
\hline \multirow{2}{*}{ 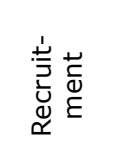 } & $\begin{array}{l}\text { Fast-stream } \\
\text { system }\end{array}$ & to attract young qualified candidates for the civil service \\
\hline & $\begin{array}{l}\text { Pooled } \\
\text { recruitment }\end{array}$ & $\begin{array}{l}\text { To effectively conduct recruitment into CS among young } \\
\text { graduates }\end{array}$ \\
\hline \multirow{3}{*}{ 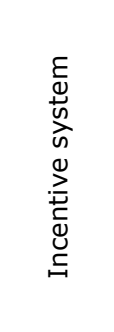 } & $\begin{array}{l}\text { Personal } \\
\text { allowance }\end{array}$ & $\begin{array}{l}\text { to increase flexibility in the pay system in order to } \\
\text { motivate high-calibre staff (decrease gap between public } \\
\text { and private sectors) }\end{array}$ \\
\hline & $\begin{array}{l}\text { Performance } \\
\text { allowance }\end{array}$ & to start merit-based remuneration linked to performance \\
\hline & $\begin{array}{l}\text { Special } \\
\text { allowance }\end{array}$ & $\begin{array}{l}\text { to attract and remunerate civil service in posts that } \\
\text { are difficult to fill or where good salaries should serve } \\
\text { as a prime anti-corruption measure (posts of superior } \\
\text { significance) }\end{array}$ \\
\hline
\end{tabular}

Source: Staroňová (2014) 


\section{Results and discussion}

\subsection{Professionalization: New types of civil service}

The Civil Service Law introduced two new types along with preparatory and permanent civil service: temporary and nominated civil service. Temporary civil service explicitly covers so-called "political functions", functions which are elected and recalled by the Parliament or appointed and recalled by the President, the Government, the President of the Parliament, the Chairman of the Constitutional Court. The performance of a political function is considered to be a performance of a public function. None of the political functions' tenure is explicitly tied to that of the appointing authority; however, in practice they are. On the level of the ministry these include: state secretary, head of the service office, head of and staff of the minister's cabinet. In addition, the amendment to the Civil Service Law in 2002 also included advisors into the law under the term of "professional performing tasks for a member of the Government, the President, Chairman of the National Council or Vice-Chairmen of the National Council". These professionals also take the form of so-called temporary civil service with a maximum employment of five years. Not all provisions of the law are, however, applicable to the political appointees, e.g. the possibility to appoint to temporary civil service without selection procedure.

Nominated civil service was brought in by the 2003 reform, which was to reward top officials with specific salaries (a $50 \%$ pay increase) and job protection in the form of security of tenure together with pension and health benefits. Civil servants applying for nominated civil service needed to pass a nomination exam (see later discussion on recruitment). It was expected that approximately 1000 civil servants would be part of the "nominated service" with tenure and a clear career path.

The career system in the civil service was to be managed and maintained by the Civil Service Office via so called systematization (and civil-service registry) that would include the number of permanent, temporary, nominated and preparatory civil-service posts (see Table 2), ranked by position resulting from the organizational structure of the ministry (or another state administrative body). In addition, the systematization had to state the volume of financial resources allocated for remuneration of civil servants. The systematization had to be approved by the government when discussing the draft budget and then voted on by parliament as part of the state budget.

The process of systematization created tension between the Civil Service Office and the Ministry of Finance as both considered themselves to have the authority for final decisions on the number of posts and related expenditure. In practice, it was the Ministry of Finance having the final word on expenditures for the civil servants, providing arguments that they are the members of the Government, not the Civil Service Office. As a result, ministries complained about the structure of systematization and the inflexibility in making changes and the fact that they were 


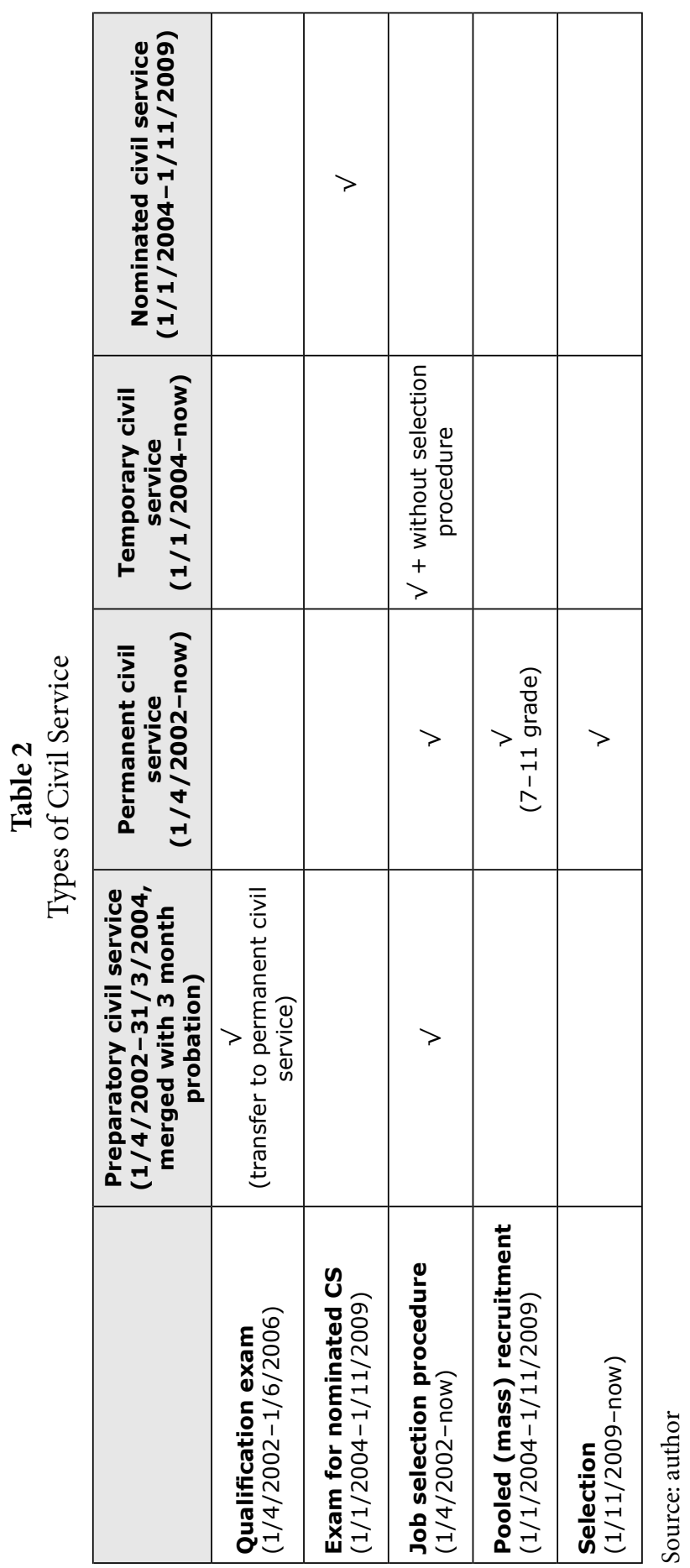


not clear on whether to contact the Ministry of Finance or the Civil Service Office. Systematization was abolished in the 2006 reform package, including the civilservice registry.

\subsection{Recruitment}

Social scientists since Weber as well as international organizations such as the World Bank agree that the method by which civil servants are recruited has important implications for governance outcomes. Rauch and Evans (2000) have linked meritocratic recruitment to higher bureaucratic performance and lower corruption, the World Bank to economic development.

Originally, recruitment was planned to be centralized and based on objective criteria and examination with all posts to be advertised openly. A system was introduced that allowed a relatively automatic career path based on seniority and at some points passing certain exams, as well as an appropriate "grade" on the annual appraisal. The Civil Service Law gave responsibility to the Civil Service Office to forecast and analyze the necessary number of civil-service posts and operational expenditure by means of systematization with a subsequent open recruitment and selection procedure. Dismissal of civil servants was largely limited by the law.

In reality, the Civil Service Office never had a crucial word in the recruitment of civil service, since already a year after its creation (2003) this task was delegated to line ministries, and only some types of recruitment (nominated and fast-track recruitment) were left to central coordination (see Table 3). 2003 changes also introduced compressed preparatory service and merged it with the probation period which shortened the preparatory service period from originally 6-24 months to 3 months and abolished the system of qualification exams from preparatory into permanent civil service.

Table 3

Civil Service Office recruitment: centralized vs. delegated selection procedure

\begin{tabular}{|l|c|c|c|c|c|c|}
\hline & $\begin{array}{c}\text { Since } \\
\mathbf{2 0 0 2} \text { (CSO } \\
\text { creation) }\end{array}$ & $\mathbf{2 0 0 3}$ & $\mathbf{2 0 0 4}$ & $\mathbf{2 0 0 5}$ & $\begin{array}{c}\text { Until 2006 } \\
\text { (CSO } \\
\text { termination) }\end{array}$ & Total \\
\hline $\begin{array}{l}\text { Number of open } \\
\text { positions publicized }\end{array}$ & 2000 & 4639 & 11682 & 4283 & 1291 & 23895 \\
\hline $\begin{array}{l}\text { Delegated selection } \\
\text { procedure on admin. } \\
\text { bodies }\end{array}$ & 0 & $\begin{array}{c}2067 \\
(45 \%)\end{array}$ & $\begin{array}{c}9349 \\
(80 \%)\end{array}$ & $\begin{array}{c}4184 \\
(97 \%)\end{array}$ & $\begin{array}{c}1171 \\
(90 \%)\end{array}$ & $\begin{array}{c}16717 \\
(70 \%)\end{array}$ \\
\hline $\begin{array}{l}\text { Centralized Selection } \\
\text { procedures by CSO }\end{array}$ & 256 & $\begin{array}{c}351 \\
(8 \%)\end{array}$ & $\begin{array}{c}142 \\
(1.2 \%)\end{array}$ & 202 & 79 & 1030 \\
\hline
\end{tabular}

Source: author, based on reports of the Civil Service Office for years 2002, 2003, 2004, 2005 and 2006. 
Fundamental changes introduced in 2006 abolished most elements of the merit system just a few weeks before the elections in 2006. The Civil Service Office was terminated (on the grounds of its ineffectiveness), and its functions were largely decentralized to the ministries or simply ceased to exist (e.g. the entry examinations became simple job interviews). Moreover, the 2006 changes provided the head of office at a ministry (a political post from 2003) a new autonomy to dismiss a superior officer within their direct management without stating reasons. Thus, top managerial positions such as directors generals became de facto political positions. This, naturally, raises questions about the quality, transparency and impartiality of the dismissal and recruitment process. At that point, however, it was clear that there will be government change, and this provision opened the space for better coalition formation.

\section{Introduction of the fast-stream system}

The package of 2003 amendments introduced an internal and an external faststream system in order to attract qualified candidates for the civil service. The faststream system took the form of:

a) a pooled recruitment system for applicants from outside the civil service;

b) nominated civil service for applicants from inside the civil service.

The pooled recruitment system was inspired by EU countries and their faststream system, which enables rapid career growth and is the key to attracting very capable people to positions in the civil service. Thus, the purpose of this procedure was to select persons with an innovative and creative approach to problem-solving. Since the introduction of the pooled recruitment system, there were 3 rounds altogether with the following results:

\begin{tabular}{|c|c|c|}
\hline & Number of Applicants & Successful Candidates \\
\hline 2003 & 629 & 17 \\
\hline 2004 & 265 & 11 \\
\hline 2005 & 313 & 14 \\
\hline
\end{tabular}

Recruitment for nominated civil service had even worse results. According to the former head of the Civil Service Office, only 5 candidates passed the exams (out of 367 applicants) in the first round in 2004, and in 2005 none of the 177 applicants passed. Following the abolition of the CSO in 2006 the organization of exams for the nominated civil service was handed over to the Head of the Government Office (a political nominee), who did not organize any exams until 2009 when nominated civil service was abolished.

Both methods of fast streaming into the civil service were not very successful in terms of the number of successful candidates and their placement. The biggest problem lies in the hybrid position-based and career-based system which has de- 
veloped in Slovakia. Although candidates had the opportunity to be "parachuted" into higher positions (salary grades 7-11 in the pooled recruitment system and top civil service with tenure for nominated civil service), the whole system is not suited for this, as there is no formal career planning system in place, but rather a position-based approach. Thus, the rigour of the examination process in the faststream system does not correspond to the real career opportunities of the successful candidate. The exams were more difficult than regular entry exams for a vacancy consisting of 5 rounds within 1 month (general knowledge test, foreign-language test, psychological test, evaluation centre for "potential" carried out by an external body, interview with a committee) as opposed to 2-3 rounds in 1 day in the regular job-vacancy interview. Despite this more rigorous testing the ministries did not offer a better job (or payment), and the successful candidates did not have faster career opportunities, as the CS Law does not incorporate a career system. Thus, when a successful candidate wanted to get a higher position he/she had to undergo new testing (this time job or post testing), which was easier than the first tests. Moreover, the ministries were reluctant to employ the successful applicants (particularly the Ministry of Finance) because they had their own criteria. Half of the successful candidates did not start their positions and career in the civil service (they were disappointed by the negative attitude of individual ministries, by the fact that despite passing more rigorous tests they ended up with the same salaries and treatment as regular civil servants, etc.).

Nevertheless, the system had the undoubted advantages of bringing qualified candidates into the top positions of the system and could be utilized further if some fine-tuning was conducted in cooperation with individual ministries.

\section{Posts of superior significance}

The 2003 reform introduced two distinctive posts with permanent special bonuses: the nominated civil service and posts of "superior significance". The nominated civil service is to reward top officials with an automatic $50 \%$ pay increase to their monetary salary base. Posts of superior significance have a permanent special bonus to their monetary salary base of $50-100 \%$ of their tariff salary, however, with an obligation to disclose their and their family's assets. These posts are designated by the Minister and head of office for tasks and priorities stemming from the Cabinet Memorandum (including EU tasks) and used to be approved by the Civil Service Office and government through systemization if additional finances were required. If the ministry was able to provide the permanent special bonus from its own budget without asking additional resources from the state budget, the posts did not need to be approved by the government. There used to be approximately 300 posts of superior significance with permanent special bonuses according to systemization data, which after its abolishment are non-existent (see Table 5). In addition, there are posts of superior significance with a permanent special salary. These posts are designated by ministers and heads of office in the appropriate ministry and ap- 
proved together with the proposed salary by the government in order to oversee the process. The salary is calculated on the basis of a comparison with the private sector. Under Dzurinda's government in 2002-2006 this was used for the following five posts quite successfully: Head of the State Treasury, Head of the Debt Management Agency, Chief Economist at the Ministry of Finance, Head of the Anticorruption Unit at the Government Office and Head of Programming of Structural Funds at the Ministry of Labour, Social Affairs and Family (see Table 4). Posts of superior significance had the aim of attracting and remunerating civil servants in posts that were difficult to fill or posts where good salaries should serve as a prime anti-corruption measure. These measures have been evaluated very positively because highly qualified staff was attracted and also the obligations under this regime are a counterbalance for higher-base salary.

Table 4

Posts of superior significance

\begin{tabular}{|l|c|c|c|c|}
\hline & & $\mathbf{2 0 0 4}$ & $\mathbf{2 0 0 5}$ & $\mathbf{2 0 0 6}$ \\
\hline $\begin{array}{l}\text { Posts of superior } \\
\text { significance with } \\
\text { special bonus }\end{array}$ & Planned & 268 & 401 & 428 \\
\cline { 2 - 5 } & Real & 230 & 342 & 353 \\
\hline $\begin{array}{l}\text { Posts of superior } \\
\text { significance with } \\
\text { special salary }\end{array}$ & Planned & 2 & 5 & 3 \\
\cline { 2 - 5 } & Real & 2 & 5 & 2 \\
\hline
\end{tabular}

Source: author, on the basis of systemization documents of the Civil Service office.

Note: Systemization was abolished as of 1 June 2006, and no data are available further on.

\subsection{Incentive system}

Fiscal constraints make an overall increase in wage levels virtually impossible. If wages are so low in the public compared to the private sector, as it is/was everywhere in the Central and Eastern European region in the 1990s (Verheijen 1999; Láštic 2010), it is impossible to find enough, if any, qualified candidates for certain civil-service positions. A study of the World Bank (2007) on the administrative capacity of the new member states pointed to the same problems. In addition, seniority holds little attraction for the young workforce in these countries and thus neither does the traditional rigid system of salary grades.

\section{Loosening the rigidity}

The reform of the pay system in civil service in 2003 has abolished some rigid elements such as seniority, increased employees' responsibility and obligations with emphasis on performance; payment classes have been enlarged from 9 to 11, with the highest classes reserved for senior civil servants; and innovative elements for attracting and motivating staff have been introduced. Even with the reforms in pay 
tables, the desired compression ratios did not materialize (remaining approximately 1:3, well below the 1:6 benchmark of the World Bank). Thus, exceptions from the general pay rules had to be made in order to fill important positions. This was exactly the main argument for "loosening" the rigidity of the merit system in Slovakia. The aim was to build a clear distinction between top-level civil-service posts and lower-level posts, including a de-compression of the salary system and the creation of much improved employment conditions for top-level officials via the payment of bonuses (see Table 5).

As a first step, Slovakia has moved towards replacing systems based mainly on seniority with performance-based systems by removing seniority elements and introducing a "performance-based points system", although this has not been properly embedded in the system. Moreover, Slovakia has attempted to institutionalize flexibility in pay systems, particularly in the payment of bonuses. The personal allowance may be as high as $100 \%$ of the basic salary. Each ministry decides internally on the amount and mechanism of the payment of bonuses for its civil servants, and this information is not publicly available on the grounds of data protection. In reality, however, it is typically negotiated between the civil servant and his/her employer (director general and then approved by the head of service office), and the negotiations take place before the actual assessment period. This kind of bonus effectively becomes a part of the fixed salary. As a result, a hybrid system exists: the basic classification system is for the general civil service, while there is a positionbased system for top officials with negotiated salaries for that position.

During the functioning of the Civil Service Office and systematization, the Ministry of Finance and line ministries have institutionalized an informal arrangement through which funds saved on vacant positions when conducting restructuralization can be used to increase wage levels through personal allowances that can range up to $100 \%$ of pay. Reorganization to gain additional funds for bonuses, however, has not proved to be possible in all ministries, as they differed in the number of staff and their stage of reorganization. Relatively small ministries simply did not have the opportunity to slim the offices to keep finances for bonuses. Moreover, this informal system was not sustainable in the long run as the ministries deliberately overestimate the number of posts needed in annual budget discussions with the Ministry of Finance in order to keep the unspent finances for remuneration.

Some ministries have made good use of the new human-resource flexibility brought by the 2003 amendment to the Civil Service Law to attract young and highquality candidates. Particularly, the Ministry of Finance became an outstanding example in the 2003-2006 era (and with the change of Government in 2006 the only one where staff remained the same even in high positions), which became generally recognized as a very highly performing organization with good leadership, highquality staff and a strong esprit de corps. This was also recognized internationally when in June 2006 the Ministry was the first Central European central-government 


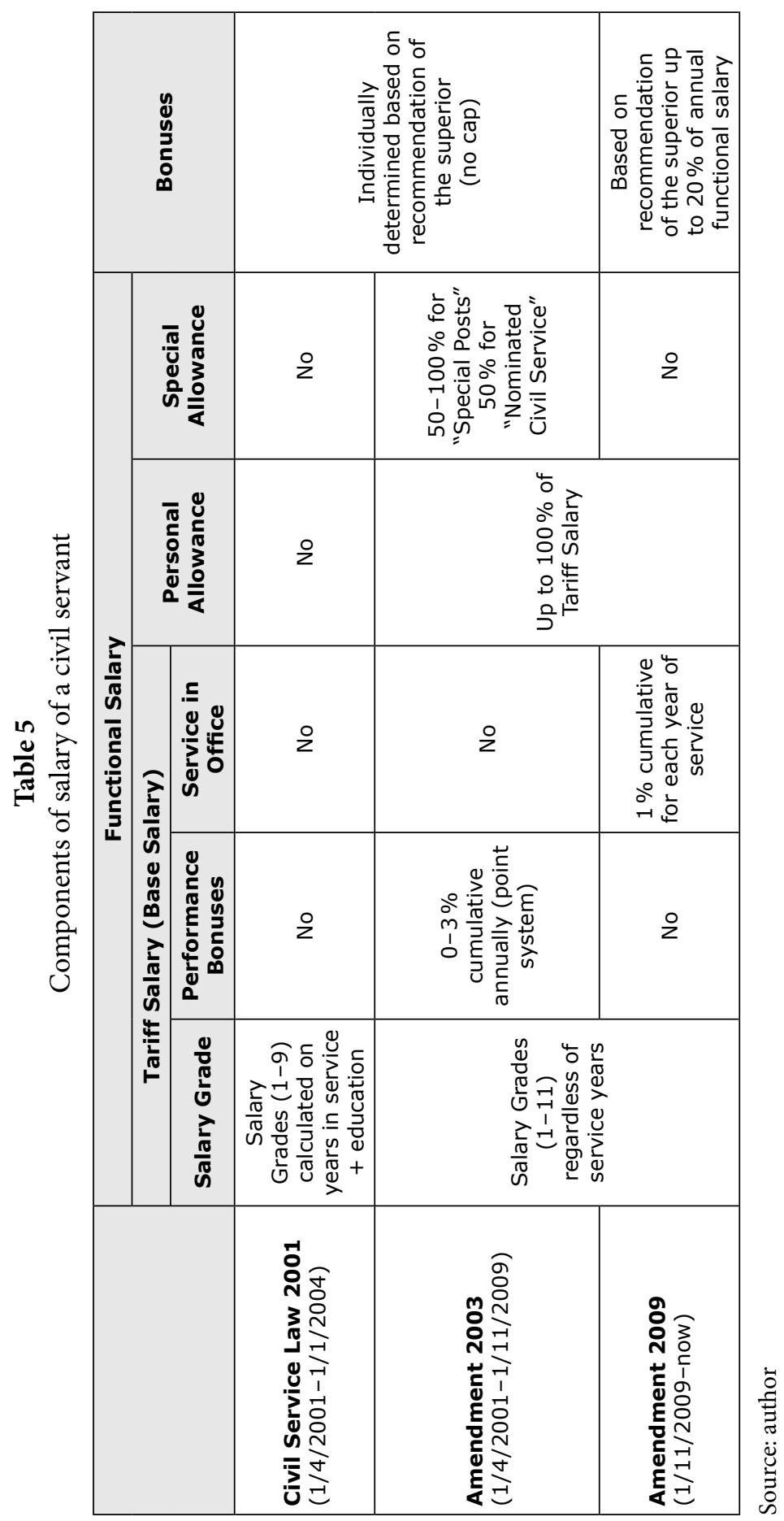


institution to obtain the "Recognized for Excellence" award within the European EFQM quality model.

Although differences exist across the ministries in the average personal allowances paid, Staroňová and Láštic (2012) calculated the trends in the remuneration in the civil service and clearly showed that liberalization of the Civil Service Law in 2003 brought the possibility for the ministries to provide higher bonuses for top civil servants, and this possibility actually increases the compression ratio and brings it to the level of private-sector managers. The calculation of the annual take-home salaries of Directors General showed that in some ministries they would earn up to three times their basic salary, i.e. the basic salary is equivalent to 35 per cent of the final salary (Staroňová and Láśtic 2012).

Whereas flexible payment of bonuses helps to overcome the problems of the highly formalized and grade-based base-pay system, the lack of clearly defined criteria for the allocation of bonuses as well as the ad-hoc nature of the system, based as it is on artificially construed wage budgets, make it vulnerable to politicization and risks creating wage-budget levels that have little to do with the real needs of the administration.

The 2003 package of changes introduced a first step towards a new system of job evaluation and appraisal - the so called "performance-based points system". On an annual basis each civil servant was evaluated by his or her superior using a points system (1-4) which could bring him or her permanent additional performance-related pay (up to $3 \%$ annually that are cumulative in nature) or lead to the termination of employment. This was at least a potential albeit rudimentary start for a performance-management approach using individual objectives and targets as the basis for appraisal. Data from the period 2004-2005 show that $45 \%$ of civil servants received the available maximum of a $3 \%$ increase based on performance, followed by $41 \%$ of civil servants with $2 \%$ increase (Staroňová and Láštic 2012). Thus, we can see that this mechanism has not been used for real performance evaluation but as a substitute for an additional permanent annual increase of salary and was abolished in 2009.

Some ministries have experimented with performance-management systems internally, particularly the Ministry of Finance, with big success. The lack of a strong central driver for institutional reform overall has led to a decentralized approach to PFP that has created strong disparities in overall government capacity and has reduced the overall effectiveness.

\section{Personal Allowances}

The personal allowance may be as high as $100 \%$ of the monetary salary base for quality fulfilment of service tasks. Nevertheless, it is already negotiated in the contract of the civil service and only non-fulfilment of the tasks results in cuts in the personal allowances. In addition to the personal allowance, also bonuses can be 
provided for targeted output or high-quality work. Each ministry decides internally on the amount and mechanism of the payment of both personal and reward bonuses for its civil servants, and this information is not publicly available on the grounds of data protection.

\section{Discussion and Conclusion}

The communist legacy is a complex and a multi-layered phenomenon. In this paper, our aim was to map changes in the human-resource management that the central government developed and introduced in the 2003 reform package as well as to show to what extent they worked (or did not work) in practice. We have tried to show how the major changes from 2003 (many of which imitate major innovations in NPM style, such as performance appraisal, remuneration flexibility) have not implied a radical cultural transformation towards professional and meritocratic public administration. In fact, most of them did not survive longer than 5-6 years and even prior to their termination they were mostly dysfunctional and non-effective (Table 6).

This study focused on the reform items introduced in 2003 by NPM-oriented government in order to examine the ways communist legacy slowly materialized in practice. Originally, many of the reform changes were in direct conflict with inherited ideas and structures that have been institutionalized over decades in the form of communist tradition. This is particularly the case in discretionary decisionmaking in HR by politicians. Thus, the idea of centrally coordinated recruitment and remuneration (institution of nominated civil service, pooled recruitment, fast stream) was not compatible with the existing tradition of discretionary power of the political actors to be involved in HR functions. The discretionary system enables politicians to be not only policy makers but also managers in their respective ministries. Only such a fundamental change and paradigm break with the past would mean the professionalization of HR functions, which was clearly against preserved interests and institutions. In fact, only those items of change survived where the discretionary power of the political actor was not jeopardized (posts of superior significance, flexibility in personal and special allowance) and thus was compatible with the inherited communist legacy.

The principle of discretionary decision making in HR by politicians went hand in hand with one of the most deeply rooted values of the administrative culture: the vital role of bonuses as a way of achieving flexibility in the management of human resources and public-service bargains. Clearly, this goes significantly against transparent and meritocratic principles, but such a bargain is well concealed within regulations. As the analysis has shown, the concept of pay-for-performance has not been applied in a proper way but as a supplement to counter the effect of low salaries. 


\section{Table 6}

Performance (survival and effectiveness) of reform elements

\begin{tabular}{|c|c|c|}
\hline HR aspect & Measure & Performance \\
\hline \multirow{3}{*}{$\begin{array}{l}\text { Profession- } \\
\text { alization }\end{array}$} & $\begin{array}{l}\text { Temporary civil } \\
\text { service }\end{array}$ & $\begin{array}{l}\text { Survived in original form, fulfilling original goal (in line } \\
\text { with discretionary power of a line minister) }\end{array}$ \\
\hline & $\begin{array}{l}\text { Nominated civil } \\
\text { service }\end{array}$ & $\begin{array}{l}\text { Ineffective tool (central body incapable to produce } \\
\text { candidates, those which produced not accepted by } \\
\text { political figures because of the contradiction to the } \\
\text { discretionary power), terminated in } 2009\end{array}$ \\
\hline & $\begin{array}{l}\text { Posts of } \\
\text { superior } \\
\text { significance }\end{array}$ & $\begin{array}{l}\text { Survived, fulfilled original goal but altered to better suit } \\
\text { discretionary power of a politician (individual rather than } \\
\text { collective appointment) }\end{array}$ \\
\hline \multirow{2}{*}{ Recruitment } & $\begin{array}{l}\text { Fast-stream } \\
\text { system }\end{array}$ & $\begin{array}{l}\text { Ineffective tool (central body vs. discretionary power of } \\
\text { political figures), terminated in } 2009\end{array}$ \\
\hline & $\begin{array}{l}\text { Pooled } \\
\text { recruitment }\end{array}$ & $\begin{array}{l}\text { Ineffective tool (central body vs. discretionary power of } \\
\text { political figures), terminated in } 2009\end{array}$ \\
\hline \multirow{3}{*}{$\begin{array}{l}\text { Incentive } \\
\text { system }\end{array}$} & $\begin{array}{l}\text { Personal } \\
\text { allowance }\end{array}$ & $\begin{array}{l}\text { Survived, effective tool (fits discretionary power of a line } \\
\text { minister) }\end{array}$ \\
\hline & $\begin{array}{l}\text { Performance } \\
\text { allowance }\end{array}$ & Ineffective tool, terminated in 2009 \\
\hline & $\begin{array}{l}\text { Special } \\
\text { allowance }\end{array}$ & $\begin{array}{l}\text { Survived, fulfilled original goal but altered to better suit } \\
\text { discretionary power of a politician (individual rather than } \\
\text { collective decision) }\end{array}$ \\
\hline
\end{tabular}

Due to incentives to conform to the Western civil-service institutions and practices, communist legacy might be not immediately visible. The European Administrative Space as a "constructed" European tradition certainly provided pressure in the accession period to adopt "foreign transplants", such as the Civil Service Office that was to overcome politicization and provide coordinated strategic HR policy in civil service. Nevertheless, these did not succeed to overcome the highly fragmented administrative system and complex coalition politics. When the base of the organization is weak, other management techniques have a poor and unreliable foundation to build on. As a result, many reform elements were utilized only in some ministries to a big benefit but did not succeed in rolling out to the administration as a whole. In fact, some of the items appeared to change rhetorically (e.g. nominated civil service) or in the short run to replace old institutions, while in reality or in the long run established patterns returned and prevailed.

The Slovak case shows that in spite of the political and economic changes during the transition period, in spite of a strong Europeanization process with an attempt to create a "European administrative tradition" which brought about Civil Service law with strong meritocratic elements, and in spite of endogenous reforms with NPM elements to increase the professionalism and attractiveness of the civil service, the communist legacy has managed to survive and resurface without chang- 
ing its deep-core structure. The focus on communist legacy in HR management in civil service can further help us understand the underlying processes within publicadministration systems in post-communist countries. This conclusion may be useful when studying other Central and Eastern European civil-service systems and influences of administrative cultures upon the reality.

\section{Acknowledgements}

This article is the result of a research project supported by the Ministry of Education under Grant No. APVV-0880-12.

\section{References}

Ekiert, G. and S. E. Hanson. 2003. Capitalism and Democracy in Central and Eastern Europe: Assessing the Legacy of Communist Rule. Cambridge: Cambridge University Press.

Goetz, K. H. and H. Wollman. 2001. "Governmentalizing Central Executives in Post-Communist Europe: A Four Country Comparison.” Journal of European Public Policy 8(6), 864-887.

Láštic, E. 2010. "Can’t Have it Both Ways? Administrative Capacity of European Affairs." In D. Malová et al. (eds). From Listening to Action? New Member States in the European Union. Bratislava: FiFUK, pp 145-166.

Meyer-Sahling, J. H. 2004. "Civil Service Reform in Post-Communist Europe: The Bumpy Road to Depoliticisation." West European Politics 27(1), 71-103.

Meyer-Sahling, J. H. 2009a. "Varieties of Legacies: A Critical Review of Legacy Explanations of Public Administration Reform in East Central Europe." International Review of Administrative Sciences 753), 509-528.

Meyer-Sahling, J. H. 2009b. The Sustainability of Civil Service Reform in Central and Eastern Europe Five Years after Accession. SIGMA Paper 44. Paris: OECD Publications.

Meyer-Sahling, J. H. and K. Yesilkagit. 2011. "Differential Legacy Effects: Three Propositions on the Impact of Administrative Traditions on Public Administration Reform in Europe East and West." Journal of European Public Policy $18(2), 311-322$.

Nunberg, B. 1999. The State after Communism: Administrative Transitions in Central and Eastern Europe. Washington, D.C.: World Bank Publications.

Painter, M. and B. G. Peters (eds). 2010. Administrative Traditions: Inheritences and Transplants in Comparative Perspective. Basingtone: Palgrave. 
Peters, G. and J. Pierre (eds). 2004. Politicization of the Civil Service in Comparative Perspective. New York: Routledge.

Peters, G. 1999. Institutional Theory in Political Science. The New Institutionalism. London: Pinter.

Rauch, J. E. and P. B. Evans. 2000. "Bureaucratic Structure and Bureaucratic Performance in Less Developed Countries." Journal of Public Economics 75, 49-71.

Sigma. 1998. Preparing Public Administrations for the European Administrative Space. SIGMA Paper 23. Paris: SIGMA.

Staroňová, K. 2014. "Innovative Elements in Civil Service Reform of Slovakia.” Paper Presented at the $21^{\text {st }}$ NISPAcee Annual Conference 2013, Regionalisation and Inter-regional Cooperation, Belgrade, 16-18 May 2013.

Staroňová, K. and G. Gajduschek. 2013. "Civil Service Reform in Slovakia and Hungary: The Road to Professionalisation.” In C. Neuhold, S. Vanhoonacker and L. Verhey (eds). Civil Servants and Politics: A Delicate Balance. London: Palgrave, $123-151$.

Staroňová, K. and E. Láštic. 2011. "Regulácia politicko-administratívnych vzt’ahov na Slovensku v rokoch 1990-2010" [Regulation of politico-administrative relation in Slovakia 1990-2010]. In M. Beblavý, E. Beblavá et al. (eds). Koaličná zmluva či zákon? Právna úprava a realita politicko-administratívnych vztiahov na Slovensku. Prešov: Michal Vaško, 33-83.

Staroňová, K. and E. Láštic. 2012. "Into the Labyrinth: The Rewards for High Public Office in Slovakia." In: B. G. Peters and M. Brans (eds). Rewards for High Public Office in Europe and North America. London: Routledge, 248-268.

Verheijen, T. (ed.). 1999. Civil Service Systems in Central and Eastern Europe. Cheltenham: Edward Elgar.

Verheijen, T. (ed.). 2001. Politico-administrative Relations: Who Rules? Bratislava: NISPAcee.

Verheijen, T. 2010. “The New Member States of the European Union: Constructed and Historical Traditions and Reform Trajectories.” In: M. Painter, G. Peters (eds). Tradition and Public Administration. London: Palgrave Macmillian, Pp. 217-233.

World Bank. 2007. EU-8: Administrative Capacity in the New Member States: The Limits of Innovation? Washington, DC: World Bank. 


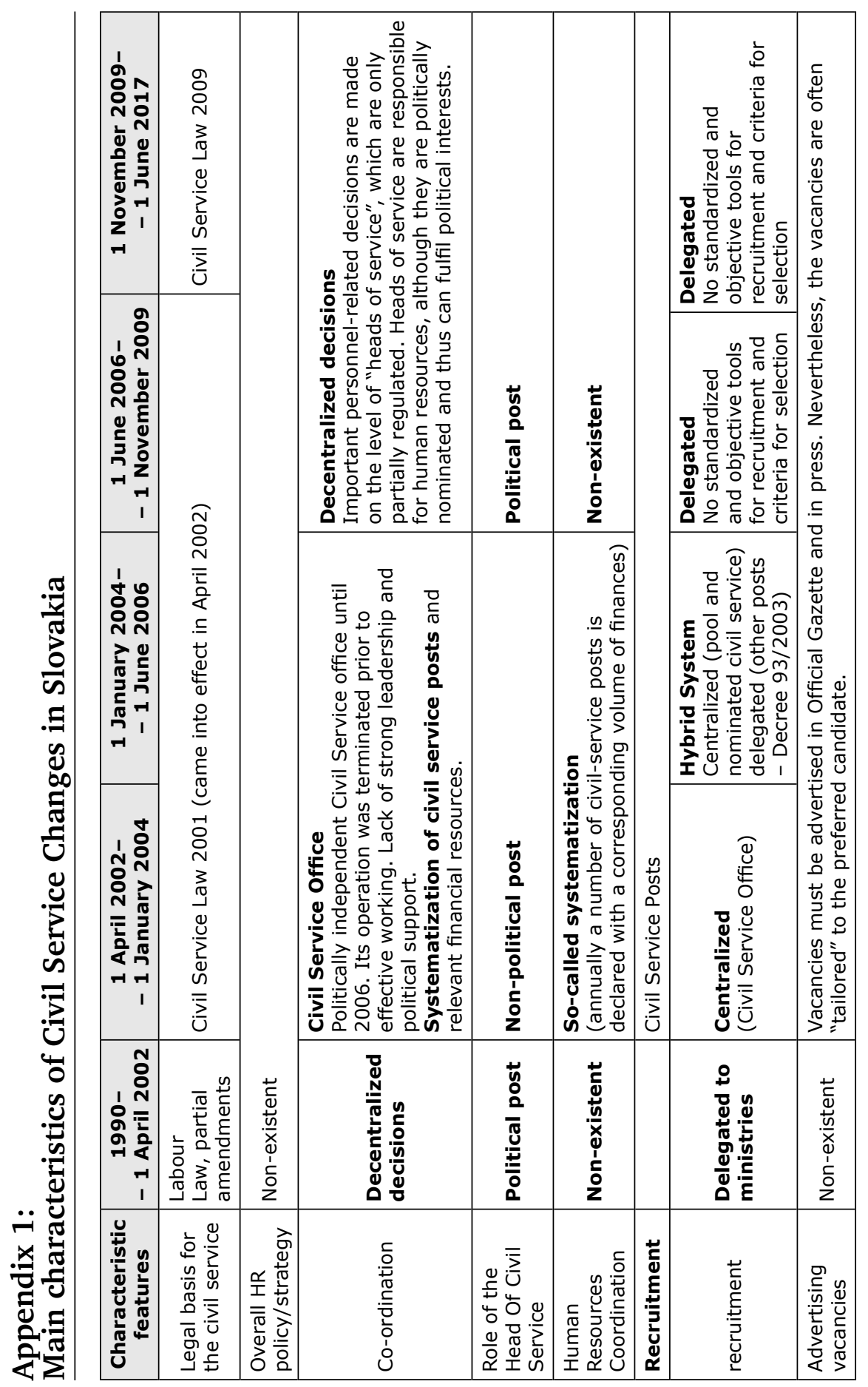




\begin{tabular}{|c|c|c|c|c|c|}
\hline 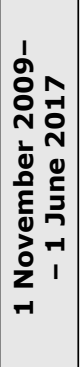 & 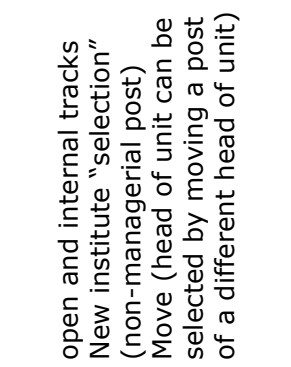 & 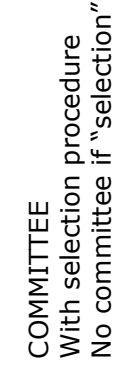 & 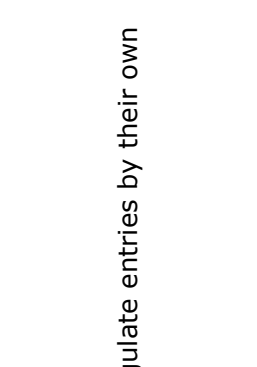 & 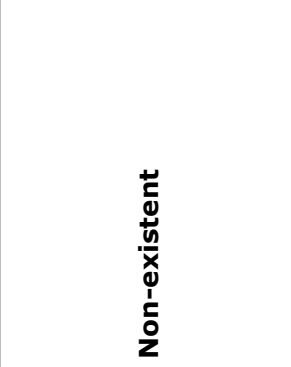 & \\
\hline 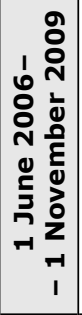 & 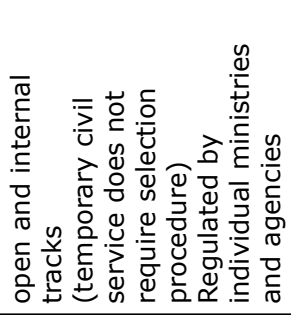 & 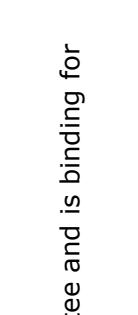 & 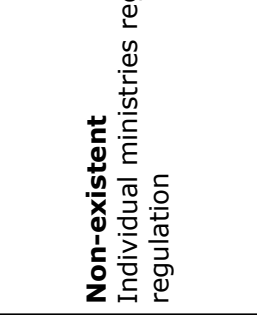 & 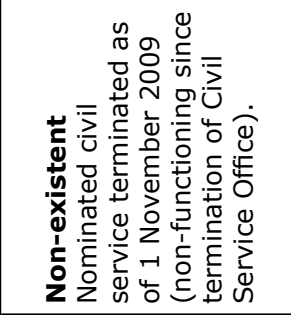 & 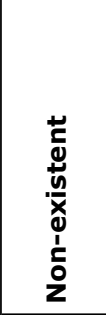 \\
\hline 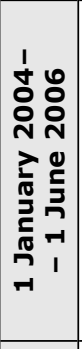 & 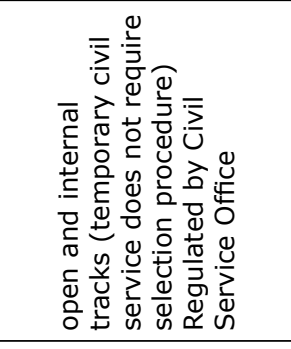 & 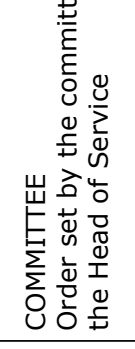 & 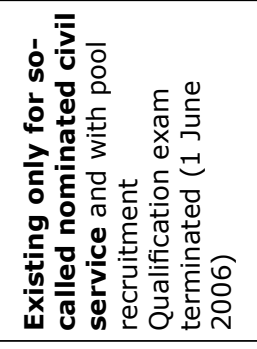 & 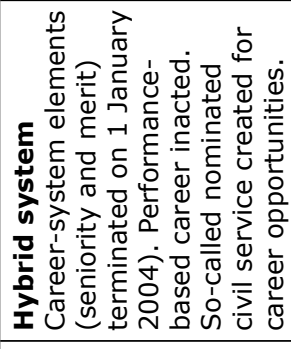 & 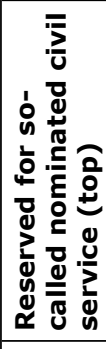 \\
\hline 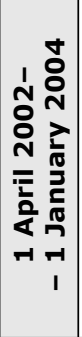 & 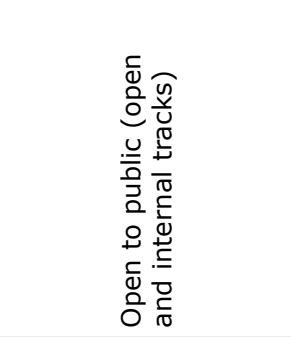 & 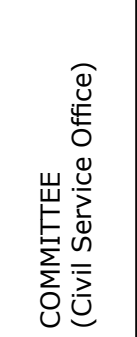 & 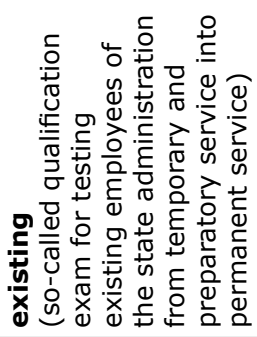 & 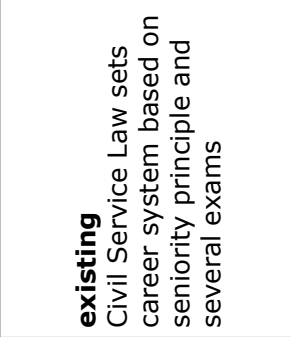 & 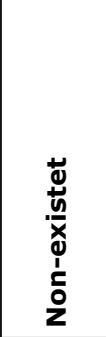 \\
\hline 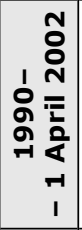 & 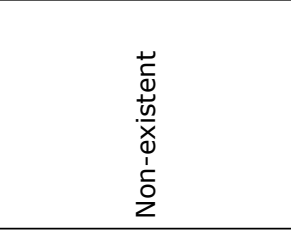 & 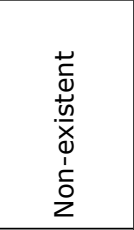 & 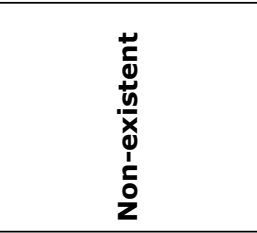 & 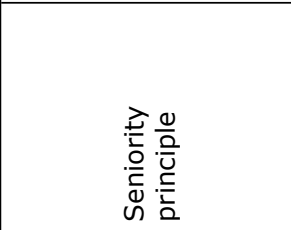 & 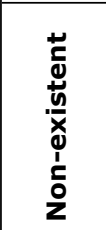 \\
\hline 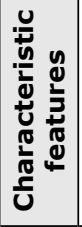 & 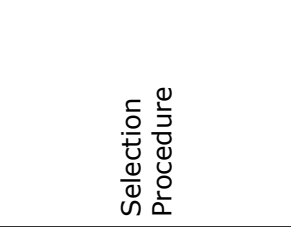 & 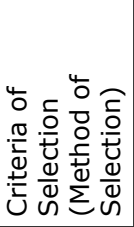 & 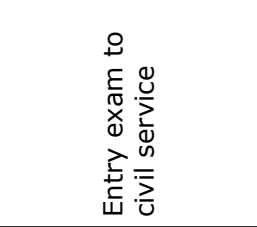 & 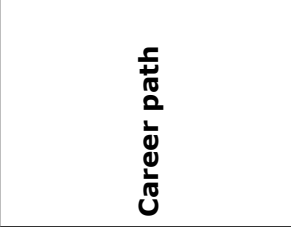 & $\begin{array}{l}0 \\
\frac{0}{3} \\
\stackrel{0}{0} \\
\qquad\end{array}$ \\
\hline
\end{tabular}




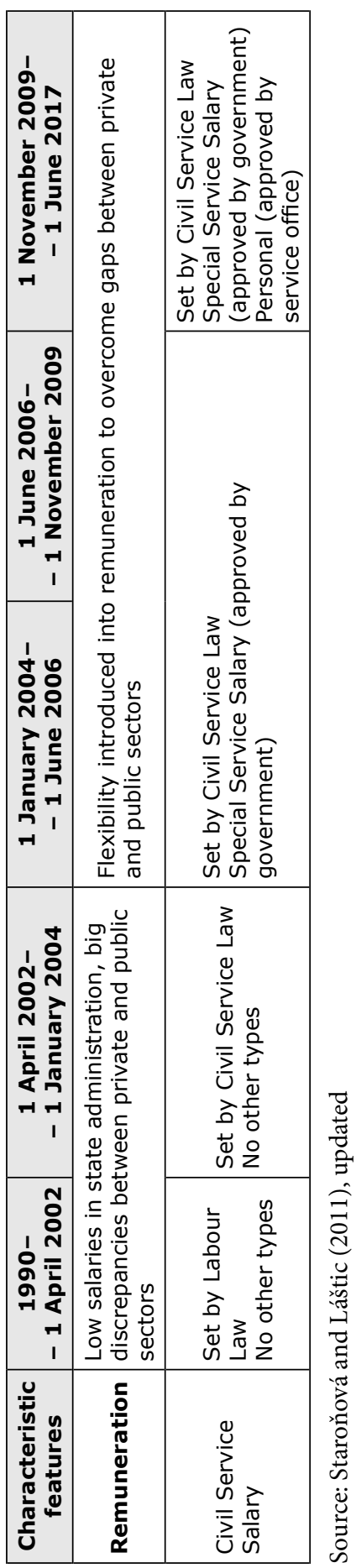

